\title{
KERK EN GENESING - 'n HISTORIESE OORSIG
}

E BROWN

\section{ABSTRACT}

\section{THE CHURCH AND HEALING - AN HISTORICAL SURVEY.}

The church is concerned with healing. This is evident in Scripture and church history.

The problem is that differing practices and assumptions to heal the sick were developed in the course of time by Christians. The church historian realizes how necessary it is to scrutinize the concepts of "the church" and "healing" in a Scriptural sense. The church is God's concern for man as a corporalitas animae. Healing is part of its calling and ministry. It is no special ministry endowed to particular individuals. The church and healing is God's doing promised in his Word and realized by his Spirit. In doing so He uses the elder within the congregation, the minister and the medical doctor.

\section{INLEIDING}

Kerk en genesing moet telkens weer Skriftuurlik verantwoord word. Om dit sinvol te doen, kan die kerkgeskiedenis help. Immers, die kerk se betrokkenheid by genesing het sowel 'n Skriftuurlike en historiese aanknoping as 'n kerklike oriëntering en ontwikkeiing. Dit vertoon 'n gevariëerde inkleding as gevolg van verskille in teologiese opvattings en beklemtonings. Die onderskeie tradisies en kerklike posisies hang by uitstek saam met die inbeelding en begripmatige verwerking wat gegee is op die vrae "wat is die kerk?" en "wat is genesing?".

'n Kerkhistoriese oorsig van 'n aspek van die christelike geloof is natuurlik altyd afhanklik van sowel die beskikbare primêre bronne as die mate waarin hulle reeds bestudeer is. Die tema is nog nie behoorlik omvattend nagevors nie. M T Kelsey het wel 'n poging aangewend in sy werk Healing and Christianity, in ancient thought and modern times. ${ }^{1}$ In die loop van die uiteensetting sal aanduiding gegee word van studies wat reeds met betrekking tot onderafdelings onderneem is.

'n Kronologiese benadering word gevolg terwyl die ontwikkeiing tipeer en voorveronderstellings aangedui word.

Genesing as 'n godsdienstige verskynsel is so oud as die mensheid self. Volgens G A Lindeboom is dit "gebore uit die nood van het leven en de drang tot helpen". ${ }^{2}$ Hierdie fenomenologiese drang het hom deurgaans 
laat geld in die geskiedenis van die geneeskunde en van die kerk.

Aanvanklik berus gesondmaking op ervaring en aanvoeling. As geneeskuns is dit deur priesters beoefen. In die Griekse kultuur is die mite van Asklepios, die god van die geneeskunde, daarvoor ontwerp. In sy gewyde tempels het kundiges die ruwe ervaring deurdink en is geneesmiddels aangewend. Reeds in 291 is die diens van Asklepios in Rome beskikbaar gestel.

Op die eiland Cos was dit Hippocrates $(460$ - 377 vC) wat homself as "vader van die (Westerse) geneeskunde" onderskei het.

In die Romeinse Ryk is Christus in die vroeë kerk nagevolg en ook gevolg gegee aan sy opdrag om in sy Naam te genees. Genesing is in terme van die Christelike geloof belewe en beoefen.

In die Skrif en vroeë kerk word na die bediening van genesing verwys. Paulus beskrywe en kwalifiseer die besondere gawes waarmee die kerk vir sy bediening toegerus was. Hieronder was die gawe van genesing charismata iamata. Soos met die ander moes die gemeente by die gawe betrek word.

As Jacobus die Evangelie aan die gemeente bedien, keer hy hom aan die einde van sy brief tot die sieke. "Laat hom die ouderlinge van die gemeente inroep", raai hy hom aan, "en laat hulle oor hom bid nadat hulle hom in die Naam van die Here met olie gesalf het". ${ }^{3}$ Vir die Nuwe-Testamentiese gelowige het aanwending van olie by hierdie ampsbediening sekerlik teruggegaan na die verbondsgebruike van die Ou Testament.

In haar werk Christian Healing ${ }^{4}$ maak E Frost 'n saak uit vir die moderne sakraments-georiënteerde bediening van genesing in die Kerk van Engeland. Sy poog om te bewys dat dit eie aan die vroeë kerk se siening is. Terwyl sy hierdie motief telkens inlees, het sy nietemin 'n omvattende ondersoek ingestel na hoe genesing ter sprake kom by die kerkvaders vanaf Clemens Romanus (95 of 96) tot met Lactantius (c 315).

In Urchristentum, sê K Beth kort en klaar, "gait r(eligiöse) $H$ (eilung) als etwas Normales". In die beoefening van die geloof is genesing in die Naam van die Heer bedien. Dit was eie aan die verkondiging van die evangelie. Dit was eie aan die toerusting van die gemeente wat van die Heilige Gees uitgaan. Die vier eerste kerkhistorici, Eusebius (c260 - c340), Sozomenus $(+443)$, Socrates (c380 - 450) en Theodoretus (c393 - c460), vermeld genesinge sonder om iets besonders daarvan te maak. Dit was nie 'n buitengewone of bykomstige bediening nie.

Genesing is belewe en beoefen as ' $n$ wesentlike deel van die geloof en 
sonder dat dit formeel beredeneer is. Die oog en hart was gerig op Christus en sy opstanding, op die Here van die lewe, op die Oonwinnaar oor siekte en dood. Christus behou die geiowige en borg vir hom die ewige lewe.

Nou is dit opvallend dat reeds vanaf die tweede helfte van die eerste eeu verneem ons nie meer van charismata, of gawes van die Heilige Gees, nie. ${ }^{6}$ Dit was slegs sektariese groepe en individue, bv die Montanisme en Tertullianus, wat nog op die inwerking van die Heilige Gees aangedring het. By hulle het die kwalifikasies van die Skrif egter verlore gegaan.

Daarmee het die bediening van genesing volgens die kontemporêre beriggewing, nie opgehou nie. Maar in die woorde van Kelsey, "there was apparently less and less of the personal element in the healings, and less psychological emphasis or understanding".

Die bediening van genesing is amptelik gereël en met die sakramente verbind terwyl dit almeer bedrywe is deur "heiliges" en heilige voorwerpe.

Algaande is die kerk met ' $n$ instituut vereenselwig en genesing in verband met die bediening van die sakramente gebring.

Kelsey vind in die Skrif ${ }^{8}$ reeds bewys vir die sakramentele begrip van genesing. "Whatever the theory about how the gift of healing was received", so beweer hy, "we find the apostles using the same basic sacramental approach to it as Jesus. Some word, a touch, or a material element such as oil was believed to convey the power that passed through the healer".

As daar aansluiting by die Skrif was, is dit tog duidelik dat met die eise van die Skrif en die persoonlike geloof in hierdie ontwikkeiing nie rekening gehou is nie. Genesing is almeer sakraal ingedink. Die liturgie waarin hierdie inkleding opgeteken staan is daarvan bewys. ${ }^{10}$

Die Didaché, 'n geskrif wat waarskynlik uit die einde eerste - begin tweede eeu dateer, hou die sakramente voor as lewe- en genesinggewend. Die Apostoliese Tradisie van Hippolitus, wat gebruike in Rome weergee, laat die olie naas die brood en wyn vir die Nagmaal seën "sodat dit troos aan almal wat dit smaak en gesondheid aan almal wat dit gebruik" kan gee. Genesing was nog 'n bediening, of eerder, gekoppel aan 'n bedienaar. Daar is ' $n$ aanduiding by Hippolitus dat aangedring is op wyding of ordening van diegene wat met die gawe van genesing bedeel was. Hy wys dit nog af, maar later sou dit 'n voorskrif word na gelang die heil almeer en meer amptelik in ' $n$ instituut gereël is.

Hierdie verḅinding van genesing aan die sakramente gaan gepaard met 'n 
bepaalde vertolking van die kerk en sy bediening wat die oorhand begin kry het. Die kerk het meer en meer 'n heilsinstituut geword wat episkopaal gereël en regeer is. Uiterlike vorm het 'n groter rol begin speel en vervlakking staan aangeteken.

Eie aan die lewe in Christus en sy grote barmhartigheid het die christen van die begin af krankes versorg en dit ook geleidelik planmatig en amptelik gereël. "Die Geschichte der Krankenpflege", wys H Schauer daarop, "beginnt trotz hochentwickelter ärztlicher Kunst und Wissenschaft der Antike erst in Christentum als 'Dienst der Hände Jesu', wobei Christus im Kranken und im Pflegenden gesehen wird, die Christen als die Herausgerufenen alles Ausgesonderten und Ausgestoszenen die Nächsten sind, besonders da, wo die ärztliche Kunst aufhört, an Seuchen-, Siechen- und Sterbebetten einschlieszlich des Leichendienstes". ${ }^{11}$ Hippolitus (c170 230), een van die uitgesproke ouderlinge in Rome, vertel hoedat onder toesig van die biskop hierdie barmhartigheidsdiens gemeentelik gereglementeer is. Die weduwees en diakens (waaronder diakonesse) het dit in die huise waargeneem. ${ }^{12}$ In hierdie diens het dit om die sieke gegaan. Nie in die eerste plek om genesing nie.

Indiwidue het voortgegaan om genesinge te beoefen. Tertullianus vertel nog tussen 197 en 213 hoedat genesinge deur indiwiduele gelowiges plaasvind. Hierdie bekende kerkvader was op een stadium onder die Montaniste, die sektariese groep wat hulle onder die sogenaamde direkte leiding van die Parakleet gestel het. Om die christelike lewe aan te beveel, verwys hy na talle gewone sowel as aansienlike mense wat genees is. Selfs keiser Septimus Severus is genees nadat 'n sekere Proculus Torpacion hom met olie gesalf en vir hom gebid het. In die verloop van tyd is genesinge geassosieer met individue wat hulle in die christelike lewe deur wonderwerking onderskei het. Hierdie "heiliges" was aanvanklik die martelare en kom later uit die geledere van die askete.

Deurentyd moes die christene rekening hou met aansprake van genesinge wat buite die kerk om gebeur het en bedryf is. Dit het veral in verband gestaan met die Griekse Asklepios kultuur en geneeshere. Justinus die Martelaar (c100 - c165) sowel as Irenaeus (c130 - c200) en Athenagoras (c177) probeer om hulle aan die kaak te stel. Opvallend is die feit dat veral na hierdie beoefenaars se motiewe verwys is. Die beoefenaar van genesing moes hom deur sy lewe aanbeveel. Clemens Alexandrinus noem Asklepios die "geldgierige geneesheer". ${ }^{13}$ Origenes (185-253) wys ewe-eens die geneeshere van hierdie kultuur af omdat hulle nie die toets van eerlikheid kan deurstaan nie en goddeloos lewe. ${ }^{14}$ Dit dui daarop dat geneeshere begin het met die beoefening van 'n professie waarin godsdienstige oortuiging sekondêr was. Tog sou valse en ware godsdienstige geloof ver- 
bind bly met genesing. Die christen apologeet Arnobius $(+330)$, wat tussen die jare 303 - 313 skrywe, het dit nog steeds teen die geneeshere wat hulle op Jupiter beroep en Christus as geneesheer afmaak. Hier is egter nou van "metodes" sprake. Hulle verkleineer die metodes van Christus, sê hy. Hy verwerp hulle wyse manne en Magiërs en wys daarop dat "geen toweragtigheid, niks mensliks, geen goëlary en geen gesigsbedrog of bedektheid" te vinde is in Christus en sy eenvoudige navolgers nie.

Toe Konstantyn die Grote die christelike geloof in die tweede dekade van die vierde eeu erken het, is die tempel van Asklepios in Rome met die grond gelyk gemaak. Die geneeshere, wat "'n houding van onverskilligheid en ongeloof ingeslaan het met die opkoms van die materialistiese geneeskunde met sy Griekse kultuur agtergrond", ${ }^{16}$ moes tot 'n vergelyk met die kerk kom. In die beoefening van die geneeskunde, waaraan die kerk voorts sou deelneem, sou hy met sy vooringenome standpunte nie altyd help met die bevordering van die wetenskap of om dit van misleidende Grieks-filosofiese veronderstellings te suiwer nie. Met die toetrede van die volksmassa sou die gebruike van die kultus van Asklepios en ander bygelowe ook in die kerke ingang vind. Aan bygeloof in verband met genesing is binne en buite die kerke deur die volk vasgehou. Vraagstelling en beskrywing in verband met genesing as 'n verskynsel en 'n praktyk vanaf die vierde eeu is nog nie na behore gedoen nie. Genoeg is egter gedoen om interpretasie in die breë aan te bied.

Met die erkenning deur die staat het die kerk in tweërlei sin ingang onder die volk gekry: amptelik as 'n episkopaalse heilsinstituut en asketies met sy kloosters. Genesing was gereël en verder in verband met die sakramente bedien terwyl die askete die bonatuurlike inkleding daarvan bevorder het. Daarmee is die sakrale en bygelowige gebruike in verband met genesing onder die volk bevorder.

Dit was hier op ons vasteland waar die Griekse kultuur met sy dualistiese uitgangspunt so sterk deurgewerk het in die beoefening van die christelike askese. In Afrika het die askeet die begeertes van die liggaam of vlees weerstaan en hom met behulp van askese van die kerker van die siel probeer bevry. Hier het hy stryd met die duiwels gevoer en sy liggaamlike behoeftes afgerem om deur God en mens heilig verklaar te word. Soos die martelare het hy die lewe "prys gegee" om die bonatuurlike te belewe. Die ideë-wêreld van Plato het sy alledaagse lewe deurkruis en ontsluit. Sy eie lewe soos dié van die martelaar het sakrale betekenis gekry en hy kon bemiddelend vir ander intree. Sy lewe het begin staan in die teken van die wonderwerking en die volk het ook die wonderwerking van genesing by hom gaan soek.

Die lewenswyse van, en gerigte oor, hierdie "heiliges" het die verbeelding 
van mense aangegryp. Athanasius (c296 - 373), wat sy lewe op die spel geplaas het ter wille van die ortodokse formulering van die leer, was een van hulle bewonderaars. Hy beskrywe in c357 die Lewe van die Heilige Antonius. Daarin is ' $n$ model van die asketiese idealisering van die christelike lewe vir die kerk in die Ooste en Weste opgestel. 'n Nuwe christelike genre, die lewensbeskrywing van die heiliges, is begin. Daarin is die christelike lewe vervleg met die bo-natuurlike en genesing met wonderwerking. Studie moet eindelik nog hierdie invloedryke ontwikkeiing vanuit die bronne ontsluit.

Die Protestant het die belewinge van die askeet afgemaak as bygeloof en subjektiewe inbeelding. So pas is maar begin om dit wetenskaplik te bestudeer. Hierin het $C$ Butler met sy werk The Lausiac History of Pailadius ${ }^{17}$ die voortou geneem.

Die askete het die kloosters aangelê en na die Ooste en Weste oorgedra. Monnike en nonne het die kerk se diens aan krankes grootliks bevorder. Maar die besondere oriëntering van die asketisme en die kloosterwese in die Ooste en Weste het die beoefening en bediening van genesing laat uiteenloop.

Vanaf die vierde eeu is dit dan veral die askeet en die klooster wat die kerk in sy bediening van genesing voorgaan. Monnike en nonne het sy diens van barmhartigheid uitgebou en inrigtings aangelê om krankes en gestremdes te versorg. Die askeet en latere biskop Basilius van Caesarea (c329 - 379), wat die Griekse kloosterwese gemodelleer het, stig die eerste inrigting vir melaatses. Hy spoor monnike aan om in hospitale te dien en herinner hulle aan die woorde van Christus in Matteus 25:35, 36. Dit is 'n werk wat met medelye gedoen moet word. ${ }^{18}$ Met 'n skenking en onder leiding van die adelike Fabiolo (+399), wat haar op een stadium by die askeet-Bybelvertaler Hieronimus yevoeg het, is die eerste hospitaal in Rome by die Portus Romanus gebou. Die monnik Thalasius rig die eerste versorgingsoord vir blindes op. Dit was 'n handelaar, Apolonius, wat die eerste gratis apteek open! Teen die einde van die vyfde eeu was valetudinaria (versorgingshuise of hospitale) reeds ' $n$ vaste instelling. ${ }^{19}$ Dit is veral in die Weste met sy ondernemende gees waar die een na die ander inrigting van die kerk geopen is.

In die Oosterse Kerk was dit die geesgenote van Athanasius wat die kloosterwese sou vestig, te wete die drie Kappadosiërs Basilius (329-379), Gregorius van Nazianzus (329-389) en eersgenoemde se jonger broer Gregorius van Nyssa (331-396).

In die reëls van die Oosterse klooster is die bediening van genesing gereglementeer en kan die kerk se besondere betekenis daarvan afgelei word. 
Selfs in die liturgie van die kerk het hierdie bediening 'n plek gekry.

Die sakramentele sin wat die vroeë kerk aan genesing gegee het, is met sy Platoniese inslag behou en verder omskrywe. Die neiging van die Oosterse kerk om te deifiseer, het hom laat geld. Sakrale voorwerpe en handelinge naas die bemiddeling van ' $n$ besondere gelowige of heilige is hierby betrek.

Met die feit van krankheid en die begeerte na genesing het Basilius, die biskop en grondlêer van die Oosterse klooster, erns gemaak. Hy het mediese opleiding gehad en was self nie gesond nie. Gregory verwys in sy lewensbeskrywing na verskeie genesings wat deur sy toedoen plaasgevind het.

In sy Langer Reëls hou hy daarmee rekening dat die monnik ' $n$ besondere probleem het ten opsigte van krankheid en genesing. Dit gaan om die vraag of medisyne te versoen is met die beoefening van vroomheid? Sy antwoord is weloorwoë: "God", so begin hy, "genees ons soms in die geheim en sonder sigbare middele as Hy oordeel dat hierdie behandeling bevorderlik vir ons siel is; en dan kan dit Hom weer behaag om materiële middels vir ons krankheid te gebruik". ${ }^{21}$

in sy dogmatiese studie, Die Groter Kategismus en Oor die wording van die Mens, behandel Gregorius van Nyssa ook genesing. Tipies van die Oosterse gees wat hy verteenwoordig, sê hy dat wonders nie met die rede begryp kan word nie, maar ons sonder twyfel laat "dat God in die natuur van die mens gebore is". En, "genesing is 'n gawe van die lewe en is goddelik". ${ }^{22}$ Hy leer verder dat die goddelike in die doop-water is en daaraan ' $n$ wonderwerkende krag verleen. Hiermee kry die sakrale inbeelding teologiese fundering. Met die wonder-genesings van Christus, sê hy, is ons oë geopen vir die opstanding, daardie kardinale dogma van die Oosterse Kerk. $^{23}$

Johannes Chrysostomus (347-407), wat die Oosterse Kerk miskien meer as iemand anders beïnvloed het, kla dat wondenwerke nie meer voorkom nie. Tog vertel hy hoedat genesings daagliks geskied as siekes hulle in die geloof salf met die olie uit die lampe wat voor die altaar van die kerk hang. In sy "doopkategese" beweer hy dat die liggaam van die martelare vir die gelowige bewaar word om of die liggaam of die siel te genees. Hulle vra nie ons tyd en geld soos die geneesheer nie! $!^{24} \mathrm{Na}$ sy mening is die duiwels die hoofoorsaak van die siekte.

Wat genoemde vier teoloë oor die bediening van genesing in die Oosterse Kerk te sê gehad en geleer het, is in die liturgie weerspieël. ${ }^{25} \mathrm{Ge}$ nesing het 'n plek in die erediens gekry. Beter gestel, aanbidding moes tot 
genesing van siel en liggaam dien.

Die sakramentele inkleding van die vroeë kerk is behou. Die Egiptiese monnikbiskop Sarapion $(+360)$ het die gangbare opvatting in sy gebedeboek onder die volgende woorde gebring: "die eucharistie is die besondere medisyne vir die lewe om tot die genesing van elke siekte te dien". ${ }^{26}$ Ook die doop is verbind met genesing.

Soos die Canones van Hippolites bepaal die Apostoliese Constitutiones, met sy Siriese agtergrond (einde vierde eeu), dat die bedienaar van genesing georden moet word. Ook diegene wat duiwels uitdryf. ${ }^{27}$ Siekebesoek word ' $n$ ampstaak van die biskop terwyl priesters wat siekes besoek in staat moet wees om te genees. ${ }^{28}$ In die formuliere vir die bevestiging van biskoppe, ouderlinge en diakens gaan die gebed op dat hulle "gevul word met die gawe van genesing". Handoplegging is deurgaans gebruik. Kelsey som die ontwikkeling in die volgende woorde op: "What had been a charisma given to individuals was becoming a part of the priestly office, to be sought and used through the sacraments".

Naas afsonderlike dienste vir krankes is gebede geformuleer om olie en ander voonwerpe beskikbaar te stel om genesing elders te bewerk. "Oil in particular", vat Kelsey weer saam, "was a 'sacramental' that could heal when power was given through the prayers and sacraments of the church. And the shrines of the martyrs, both in the eastern church and in North Africa had become to have the same power, for in the remains of a martyr holiness and therefore healing were seen as being still implicit, by the sacrament of their devotion and death".

In die Westerse Kerk het die bediening van genesing, wat in die vroeë kerk aangelê en in die Oosterse Kerk verder gevoer is, in die slag gebly. Die volksgeloof het voortgegaan om genesing in die sakramente en by die sakrale te soek. Maar as ' $n$ bediening in eie reg is dit nie in die liturgie opgeneem nie. Siekte het 'n positiewe heilswaarde gekry terwyl genesing simboliese betekenis verkry het en met boetedoening verbind is.

Hierdie geloofsverandering het plaasgevind al na gelang die Platoniese benadering in die amptelike oriëntering plek gemaak het vir dié van Aristoteles. Kelsey vind die begin van hierdie afwyking van die vroeë kerk se tradisie van genesing by die vroeëre-Augustinus, die teoloog par exce/lence van die Weste. In sy eerste werke stel hy dit duidelik dat die Christen hom nie moet instel op die voortsetting van die gawe van genesing nie. Slegs aan die einde van sy lewe, toe hy die laaste hoofstuk van sy Stad Gods voltooi het, verwys hy na genesings in sy eie bisdom. In sy Retractationes, waarin hy van sy leerstellings terugtrek of regstel, kwalifiseer hy sy standpunt. Hy het nie bedoel, sê hy, dat genesinge nie meer voorkom nie. 
Inteendeel, hy het so pas weer ervaar hoedat "'n blinde man na die liggame van twee martelare in Milaan gegaan en in daardie stad sy gesig teruggegee is...". ${ }^{32}$ Paulinus, die sekretaris en biograaf van Ambrosius, vertel in hierdie verband hoe iaasgenoemde deur die openbaring van 'n droom hierdie twee martelare se lyke opgespoor het. Hierdie bekende biskop was inderdaad bedrewe met wonderwerke en genesings.

Verhale van wonderbaarlike gebeure het in die Weste nie ontbreek nie. Hiervan lewer die oorkondes in verband met die invloedryke Martinus van Tours (316 (335) - 397 (400) bewys. Dit is oorlaai met die "onmoontlike" waarin vroomheid en verbeelding hoogty vier. Sy tyd was seker daarvoor te vinde, maar sy toewyding aan God en mens het dit sekerlik ook vir sy tydgenote "waar" gemaak.

Die kerk het in elk geval die gelowige aan bygelowigheid oorgelaat terwyl hy dogmaties met Augustinus se voorveronderstelling voortgegaan het. Ten spyte daarvan dat hy self net voor sy dood genesinge waargeneem het, kry genesing in sy dogmatiese besinning nie weer aandag nie. Die Weste het genesing as 'n ampsbediening prysgegee. Dit is voorts beskou as 'n gawe van 'n besondere tyd wat verby is. Kelsey vind nog drie redes waarom dit gebeur het, te wete ' $n$ veranderde beskouing van God en die mens, wat intree na die verval van die beskawing en die inval van die barbare; die aanvaarding van Aristoteles se rasionalisme, wat weinig plek laat vir direkte kontak tussen God en mens, en die bygelowige wyse waarop die populêre mening vasgehou het aan wonderwerking en genesing, wat laasgenoemde onder verdenking gebring het. ${ }^{33}$ Tiperend van die ontwikkeling is die feit dat in die Vulgaat Hieronymus (c342-420) sonder meer die term salvo gebruik vir beide "red" en "genees". Hierop is Kelsey se kommentaar: "Whatever his personal reasons, Jerome helped to turn the church's attention away from healing itself, focusing it on what healing represented symbolically". ${ }^{34}$

Die kloosters is gemaan teen die gevare van die beoefening van genesing. In die Conferences van Cassianus (360-435), een van die werke wat die grondlêer van die Westerse kloostenwese Benedictus van Nursia (c480 - c550) voorgeskrywe het, word dit gedoen. Genesings het wel nog voorgekom en is deur monnike beoefen vir 'n spesifieke doel, naamlik om die krag van God aan ketters of spotters of hulle wat uitdagend teenoor die monnik staan, te bewys. Hy waarsku egter die monnik teen die beoefening daarvan omdat "dit nie slegs nederigheid nie, maar ook innerlike reinheid en volkome kuisheid in gevaar stel." Toe Gregorius die Grote in 590 pous word en aan die Westerse Kerk verder beslag in terme van 'n heilsinstituut gee en die kloosters daarby amptelik inskakel, het hy by bogenoemde raad aangesluit. Siekte het positiewe geloofswaarde: dit dwing die mens 
om oor sy sonde na te dink en berou te hê. Daarmee het hy nie sonder meer geneeskunde en "geneesmiddels" afgemaak nie. Hy beveel Marinianus om sy geneesheer se advies te soek en vir eers sy pastorale verpligting, vas en gebed op te skort. Om die verwoesting van ' $n$ epidemie in Ravenna teen te gaan, stuur hy vir hulle relikwieë met "genesende krag".

In die Westerse Kerk is nie aan die krag van God om te genees getwyfel nie. Maar die vraag is telkens gevra of dit sy wil is om in ' $n$ besondere geval te genees. Voorts is die geloofsbeoefening en kerklike bediening ingestel nie op hierdie lewe nie, maar op dié na die dood. Die sakrament van genesing is dienooreenkomstig aangepas: salwing tot genesing het geword unctio extrema, laaste salwing (vir die dood). ${ }^{35}$ Dit sou erken word as een van die sewe sakramente soos wat Petrus Lombardus in 1151 aandui. Dit gebeur by die skolastici wat die Westerse Kerk se teologie aan die hand van Aristoteles se denkwyse en sisteem byeengebring het. Terwyl die populêre geloofsbeoefening voortgegaan het en die "leke" deur belewinge en die tradisie van wonderwerke gelei is, ${ }^{36}$ is die rede gebruik om 'n leerstellige samevatting vir die kerk te formuleer. Thomas van Aquinas (c1225-1274) het daaraan afronding gegee en amptelik er-kenning verkry. In sy Summa Theologica, wat die standaard dogmatiek vir die kerk geword het, stel die aanvullende gedeelte ${ }^{37}$ die ruspunt van hierdie ontwikkeling: "Die Laaste Salwing is 'n geestelike geneesmiddel, aangesien dit bydra tot die verwydering van sonde, volgens Jakobus 5:15. Daarom is dit ' $n$ sakrament ... Die voorgenome doel van die bediening van die sakrament is die genesing van die siekte van sonde". Hierdie standpunt sou die Konsilie van Trent in 1551 handhaaf. In sy dogmatiese opbou het hy Christelike geloof en tradisie gerasionaliseer. God, sy skepping en die mens is opgestel in 'n natuurlike orde waarin oorsaak en gevolg die samehang uitmaak. Hierin het genesing nie 'n plek gekry nie behalwe in verband met boetedoening. ${ }^{38}$

Ondertussen is geneeskunde deur die kerk bevorder, maar nie altyd sonder spanning nie.

Die Eerste Algemene Sinode van die Weste na die formele skeiding met die Oosterse Kerk in 1054, Lateraan 1123, probeer om die sterk invloed van die monnike teen te werk en ontsê hulle 'n aandeel in die ampsbediening, onder andere ook om olie te wy en siekes te besoek. Toe die monnike begin om hulle as geneeshere en regsgeleerdes te bekwaam, keur die Tweede Lateraanse Sinode (1139) dit af dat hulle "hulle self as geneeshere van die liggaam" aanbied "aangesien 'n onsuiwere oog die boodskapper van 'n onsuiwere hart" is.

Toe die monnike van die bedelordes, in hulle strewe om mense pastoraal te bedien, snykunde toepas, verbied die Sinode van Tours in 1163 
kerkmanne hierdie behandeling omdat "die kerk die vergieting van bloed afkeur". Gevolglik het die barbier hierdie kundigheid toegepas.

In 1300 weer verbied pous Bonifacius VIII disseksie van die menslike liggaam en moes van varke gebruikgemaak word om anatomie te bestudeer. Om meer as een rede is die geneeskunde in 'n spanningsverhouding met die kerk geplaas. In 1215 het die Vierde Lateraanse Sinode op grond van die feit dat "liggaamlike gebreke soms deur sonde veroorsaak is," bepaal dat wanneer ' $n$ geneesheer ontbied word dit sy eerste verantwoordelikheid is om die priester in te roep. "Want", so word geredeneer, "as die oorsaak verwyder is, sal die gevolg verdwyn". ${ }^{39}$ In 1566 is die geneesheer verplig om die pasiënt te laat boete doen. As hy na die derde dag dit nalaat, kon hy sy lisensie verloor. In 1725 nog het die Rooms-Katolieke Kerk hierdie bepaling herhaal en verdere strafmaatreëls bygevoeg.

Gedurende die Renaissance kom daar 'n skeiding tussen sowel die kerk en die mediese wetenskap as tussen die kerk en genesingsdienste. ${ }^{40}$ Aanvanklik staan die hospitale in verband met kerklike barmhartigheidsdiens. Algaande ontwikkel hulle 'n selfstandige regsbestel in die samelewing. Dit was die kloosters, veral die Orde van Cluny die tiende eeu, die Ridderordes van die Kruistogte en die Bedelordes vanaf die elfde en twaalfde eeu wat hulle opgerig en beman het. Soos wat die stede van-af die dertiende eeu hulle bestuur self begin waarneem, is hospitale onder beheer van die stadsraad geplaas en is meer van lekeverpleging gebruik gemaak. $\mathrm{K}$ Jansen sê van hierdie ontwikkeling "Zweifellos verbindet sich damit auch eine gewisse Säkularisierung". 41 Hy wys daarop hoedat dit voorts beklemtoon is dat "die hospitaal geen kerk is nie". Die kerklike bediening is nie summier uitgesluit nie. Dit was egter die begin van 'n ontvoogding wat in die tegnies georiënteerde samelewing daarop sou uitloop dat die hospitaal al meer as "gesondheidsfabriek" beskou is.

Die Rooms-Katolieke Kerk het as heilsinstituut voortgegaan om beheer oor die hospitaal en geneeskunde in 'n amptelike sin te behou. Die Reformasie het die begrip van die kerk en sy bediening weer Skriftuurlik verantwoord. Eerder as ' $n$ heilsinstituut is die protestantse kerk 'n geloofsgemeenskap in die Naam van Christus. Die bediening gaan nie uit van die sakramente nie, maar van die Woord. Die Protestantse kerke het hierdie diens eerder laat waarneem en verantwoord deur die lidmate in die algemene amp van die gelowige. Verder moes die siekepastoraat hom in die gemeente en deur die gemeente laat geld. Siekes moes tuis en in inrigtings besoek word.

Genesing is nie aan die sakramente gekoppel nie. Die bediening van siekes moes van die Woord uitgaan en pastoraal bedien word. Oor die bediening van genesing is egter nie uitsluitsel gegee nie. Daarmee is on- 
gelukkig sektariese beskouings en praktyke van geloofs- en gebedsgenesing aan die hand gewerk.

Op die voorbede van Luther (1483-1546) is Melanchton genees. ${ }^{42}$ Telkens beklemtoon die reformatore besoek van siekes sonder om dit in verband met 'n besondere bediening van genesing te stel. ${ }^{43}$ Hulle staan sterk afkeurig teenoor die veelvuldige misdrywe en bygeloof waarmee hulle self te doen gehad het. Teologies is die siening van Augustinus Protestants ingeklee en die genesinge van die Skrif kerkhistories begrens. Dit was 'n bediening eie aan die tyd van Jesus se vleeswording. Ursinus (1534-1583), wat saam met Olevianus die Heidelbergse Kategismus op-stel, beweer sonder meer "de gezondmaking des lichaams heeft met andere miraculeuze gaven in de gemeente opgehouden". ${ }^{44}$ Calvyn (1509-1564) is heelwat versigtiger in sy kommentaar op Markus 16:17, 18 en dink dat: "... hoewel Christus nie duidelik sê of Hy die mag slegs tydelik of wel vir altyd aan sy Kerk verleen nie, is dit nogtans waarskynlik dat hier slegs vir 'n tyd wondergawes toegesê word om die nuwe Evangelie, en dit wat nog donker was, te verklaar".

Daarmee is die bediening van genesing in navolging van Christus nie afgemaak nie. Gedurende die 18de en 19de eeue met die sterk deurwerking van die rasionalisme het die Protestantse kerke (en Rooms-Katolieke Kerk) die bevindinge van die mediese wetenskap dankbaar aanvaar en hulle toegespits op die bediening van siekes. Sektariese geeste uit Protestantse geledere het met hierdie benadering nie genoë geneem nie en bedieninge van genesing in terme van ' $n$ besondere gawe bedrywe. Slegs enkelinge in die kerke het gesoek na 'n bediening van genesing wat by die Skrif en Christus aansluit.

Sedert die Protestantse Reformasie het die geneeskunde in kennis toegeneem, en met die ontwikkeiing van tegniese hulpmiddels en behandeling vir homself naam verwerf.

$\mathrm{Na}$ die eeuelange verbod van die kerk bevorder Andres Vesalius (15141564) die ontleedkunde en anatomie van die menslike liggaam. Die moderne fisiologie begin met die ontdekking van bloedsomloop deur William Harvey in 1628. "In het midden der vorige eeuw is een proses van grote vooruitgang begonnen, doordat men de geneeskunde stelselmatig als een natuurwetenschap ging beoefen en van allerlei mystieke irrationele momenten trachte te ontdoen". 45

Hierdie ontwikkeiing is gestimuleer deur die Aristoteliese rasionalisme. Sy voorveronderstellings het egter die geneeskunde nie teen misleiding gevrywaar nie. Die Protestantse en Rooms-Katolieke Kerke het die geneeskunde ook nie aan die feit gehou dat die mens 'n corporalitas animae is 
wat in verhouding met God staan nie. Die geneesheer het die liggaam van die mens probeer "regdokter", veral met gebruikmaking van tegniese hulpmiddele. In soverre as wat erken is dat hy geestelike of sogenoemde sielsbehoeftes het, is hy oorgelaat aan die kerk se sorg.

Hierdie antropologie het tot gevolg gehad dat 'n groot verskeidenheid van rigtings, sommige met 'n Christelike agtergrond, na vore gekom het om sogenaamde "geestelike" genesings moontlik te maak. ${ }^{46}$ Sektariese bewegings en individue in die kerke het "gebedsgenesing" beoefen of voorgestaan. 47

In die NG Kerk het Andrew Murray gebedsgenesing ondervind en daaroor geskrywe. ${ }^{48}$ Die besoek van die geloofsgeneser $\mathrm{J} M$ Hickson in SuidAfrika gedurende 1922 lei tot 'n konferensie in Bloemfontein van 17 tot 19 Januarie 1923 oor dié ondenwerp.

Algaande en veral in die eerste dekade van die twintigste eeu is die mistasting van hierdie dualistiese en meganiese konsepsie en benadering deur beide geneeskunde en die kerke ingesien.

In die kerke self is pogings aangewend om opnuut weer die bediening van genesing te verantwoord. Een na die ander kerkverband het reeds 'n rapport uitgebring. ${ }^{50}$ 'n Verskeidenheid van bewegings is geïnisieer om die digotomiese beskouing van die mens by genesing te voorkom. Die Immanuel Beweging wat deur die Episkopaalse Kerk in Boston in die eerste dekade van ons eeu gevorm is, het die voortou geneem. Hierdie gesprek tussen geestelikes en geneeshere gaan van die oortuiging uit dat daar 'n wisselwerking van liggaam, gees en siel is. Die Lambeth Konferensie van 1920 het hierdie samewerking verwelkom. In Engeland is hierdie benadering georganiseer in die "Guild of Pastoral Psychology" en "Churches Council of Healing".

In Oktober 1924 is die eerste teologies-mediese vakkonferensie in Hephata by Treysa gehou. Hieruit is 'n werkgemeenskap gebore wat die reeks Artz und Seelsorger publiseer. Dan is daar nog die "International Order of Luke the Physician" waaraan geneeshere behoort wat hulle professie met 'n christelike geloof en benadering beoefen.

'n Verskeidenheid van standpunte word voorgehou om weer die christelike bediening van genesing tot sy reg te laat kom. Ons noem slegs drie verteenwoordigers. Frost wil teruggaan na die vroeë kerk en 'n sakramentele interpretasie en bediening van genesing vir ons eie tyd ultwerk. ${ }^{51}$ Kelsey wil ook met 'n teologiese herfundering die bediening van genesing in die Kerk herstel. Hiervoor staan hy 'n "bevindelike" vertolking van die (Skrif en) Christelike geloof voor. ${ }^{52}$ Theron vind nie fout met die gereformeerde 
teologie se fundering nie, maar verantwoord die siekepastoraat opnuut en vir ons tyd Skriftuurlik. "Vir die genesing van krankes", so vat hy saam, "is daar één aanwysing in die Heilige Skrif, die gelowige gebed". ${ }^{53}$ Met hierdie oorvereenvoudiging wil ek verskil.

Watter lering bied die kerkgeskiedenis vir die Skriftuurlike verantwoording van die bediening van genesing? Ten minste die volgende duidings kom na vore.

Ailereers dat die Kerk se geskiedenis in dié verband normatief beoordeel moet word. Vir die gereformeerde kom dit neer op Skriftuurlike verantwoording. Dan kan kerkhistoriese tradisies oor die kerk en genesing van groot waarde wees.

Hieruit volg verder dat ons die Skrif nie deur ' $n$ vooropgestelde siening van die geskiedenis moet interpreteer nie. Hiervan was Augustinus en selfs Calvyn nie gevrywaar in hulle vertolking van Markus 16:17 en 18 nie. Die feit dat wonders en genesings nie meer in die kerk voorgekom het nie, laat ons tog nie toe om te sê dat Christus se opdrag slegs geldig was vir 'n besondere tyd, ' $n$ buitengewone periode nie. Aan die kerk is die opdrag gegee om in Naam van Christus genesing te bedien.

Om hierdie bediening in verband met die sakramente te stel, lei tot sowel inbeeldings en misbruike as sakrale misdrywing.

In Naam van die Here van die Kerk moet hierdie bediening van genesing deur sy Woord en Gees geskied.

Hierdie ampsbediening kan nie sonder die salwing van die Heilige Gees en sy begeleiding waargeneem word nie.

Dit is ' $n$ bediening wat nie as iets besonders moet aangebied word nie. Dit is wesenseie aan die evangelie en die ampsbediening van die plaaslike gemeente.

Met die feit dat die Skrif die bediening van genesing aan die ouderlinge opdra, moet erns gemaak word.

Hiermee word geneeskundige behandeling nie tersyde gestel of slegs aangevul nie. Soos die geneesheer het die bedienaar van die Woord met die mens as 'n corporalitas animae te doen.

In die siekepastoraat moet die bediening van die Woord by siekte en genesing aansluit. Hoe belangrik gebed hierin is, moet hierdie bediening nie slegs daarop uitloop nie (soos Theron geneig is om te doen). 


\section{NOTAS}

1. London 1973.

2. "Geneeskunde": Christelijke Encyclopedie, $1958^{3}, 156 \mathrm{~b}-158 \mathrm{a}, 156 \mathrm{~b}$.

3. 4.14b.

4. London $1954^{3}$.

5. "Heilung": RGG, 1959³ III, 194-8, 193. Vgl ook Kelsey a.w., 123.

6. Vgl. $\mathrm{J}$ du Plessis, "De gave der gezondmaking in de geschiedenis der Christelijke Kerk," Het Zoeklicht, I. 2, Februarie 1923 en J P Theron, Gebed en genesing in die pastorale sorg, DD-proefskrif, U P, 1969, $66 \mathrm{vv}$.

7. a.w., 125.

8. Jakobus 5:14-15.

9. a.w., 124.

10. Vgl. Kelsey, a.w., 178w.

11. "Krankenpflege", Ev Kirchen Lexikon, II, 955.

12. Can. 24w.

13. A J Dölger, Antike und Christentum, Kultuur und Religionsgeschichtiche Studien. Münster 1950, Bd VI, 241-256.

14. Contra Celsum, III, XXV.

15. Aangehaal deur Theron, a.w., 70-71.

16. Theron, a.w., 71.

17. London 1967.

18. W C L Clarke, The Ascetic works of St Basil. London 1925, 122.

19. Vgl Phyllis L Garlick, Health and Healing. London 1948, $34 \mathrm{w}$.

20. Vgl Kelsey, a.w., $167 \mathrm{w}$.

21. Vgl W C L Clarke, The Ascetic Works of St Basil. London 1925, 224w.

22. Die Groter Kategismus, XI.

23. Oor die wording van die mens, XXV vv.

24. Kelsey, a.w., 177.

25. $\mathrm{Vgl} \mathrm{Kelsey} \mathrm{a.w.,} 178 \mathrm{w}$.

26. Bishop Sarapion's Prayer Book, 1-1c (ed by John Wordsworth), London 1923, 63.

27. VIII 26.

28. VIII 199, 219.

29. a.w. 180.

30. VIII 29.

31. a.w., 180-181.

32. Retractationes, 1. 137. 
33. a.w., $201 \mathrm{w}$.

34. a.w., 194.

35. Vgl Kelsey, a.w., $207 \mathrm{w}$.

36. Vgl Kelsey, a.w., $206 \mathrm{w}$.

37. III $29 \mathrm{v}$.

38. Kelsey, a.w., $213-216$.

39. Canon 22: H J Schroeder: Disciplinary Decrees of the General Councils St Louis 1937, $263 \mathrm{w}$.

40. P L Garlick, Health and Healing, London 1948, 35.

41. "Krankenpflege": R G G, 1959, IV, 33-26, 34.

42. Tenhaeff, a.w., 168.

43. Vir ' $n$ oorsig van die gereformeerde pastorale sielsorgers sien Theron, a.w., $83 \mathrm{w}$

44. Aangehaal deur A F N Lekkerkerker, "Lrsinus Schatboek", Kerk en Theologie, 11, (1951), 249.

45. Lindeboom, a.w., 1570.

46. Vgl Theron, a.w., $96 \mathrm{w}$.

47. Vgl Theron, a.w., 125.

48. Vgl Theron, a.w., $159 \mathrm{w}$.

49. Vgl Het Zoeklicht, wat in sy eerste twee uitgawes van Januarie en Februarie 1923 die voordragte publiseer. In laasgenoemde uitgawe is die studie van J du Plessis oor "De Gave der gesondmaking in de Geschiedenis der Christelike Kerk" opgeneem.

50. Vgl Theron, a.w., 13-14 en Kelsey, a.w., 223 vir 'n oorsig.

51. Vgl die "Preface" van haar aangehaalde werk.

52. Vgl die laaste twee hoofstukke van sy aangehaalde werk.

53. a.w., 458. Vgl. sy hele slotsom, $452 \mathrm{w}$. 